\title{
Evaluation of DNA/BSA Binding and Chemical Nuclease Activity of L-Tyrosine-Based Mn(III) and Fe(III) Metallo-Intercalators
}

\author{
Biju Bennie Rajaretnam, ${ }^{1}$ Joel Chellappa, ${ }^{1}$ Daniel Abraham Solomon, ${ }^{2}$ \\ Iyyam Pillai Subramanian ${ }^{3}$ and Theodore David Manickam Selvanayagam ${ }^{4, *}$ \\ ${ }^{1}$ Postgraduate Department of Chemistry, St. John's College, Tirunelveli-627002, Tamil Nadu, India. \\ ${ }_{2}^{2}$ Department of Chemistry, Madras Christian College, Chennai-600059, Tamil Nadu, India. \\ ${ }^{3}$ Postgraduate and Research Department of Chemistry, Pachaiyappa's College, Chennai-600030, Tamil Nadu, India. \\ ${ }^{4}$ Department of Applied Chemistry, PSN College of Engineering and Technology, Tirunelveli-627152, Tamil Nadu, India. \\ ${ }^{*}$ Corresponding author: E-mail: s.theodore.david@gmail.com \\ Mobile: +919366705118
}

Received: 10-11-2018

\begin{abstract}
A novel class of $\mathrm{Mn}$ (III) and $\mathrm{Fe}(\mathrm{III})$ complexes of L-tyrosine-based ligand has been synthesized and characterized through various analytical and spectroscopic techniques. These complexes were found to exhibit efficient binding properties with the biomolecules viz. calf thymus DNA and BSA. The ability of complexes to bind with such biomolecules has been explored through absorption, emission and viscosity measurements. Based on spectroscopic techniques we can conclude that the complexes could bind to DNA via intercalation. It was observed that these complexes can cleave pBR322 DNA in gel-electrophoresis technique through oxidative mechanism. The BSA was quenched by the complexes around $340 \mathrm{~nm}$ adopting a mechanism of static mode. The binding constants, thermodynamic parameters and the donor to acceptor distance were calculated. Besides, molecular docking simulations were carried out for the complexes with human DNA topoisomerase and BSA protein. The docked poses are visualized to provide supportive evidence to the interaction of the synthesized complexes with DNA/BSA.
\end{abstract}

Keywords: BSA; CT DNA; Coordination complex; L-Tyrosine; Molecular docking

\section{Introduction}

Biomolecules such as proteins or nucleic acids are particularly interesting as the target since they act as the key molecules in the metabolic pathways associated with a specific disease. ${ }^{1} \mathrm{~A}$ drug is a molecule designed in order to obstruct the target function in the particular disease modifying pathway. The transition metal complexes containing multidentate aromatic ligands play important role in different biological processes which eventually helps to develop different structural and more importantly functional model systems. ${ }^{2-4}$ DNA is known to be an important cellular receptor. Interactions of small metal complexes with DNA and proteins are the key research areas of current years as there are enough potentials of development of new therapeutic agent particularly showing anti- tumor properties and possibility of the transportation of these molecules throughout the physiological system via protein binding. ${ }^{5-8}$ The metal complexes-nucleic acid interaction has gained the attention of researchers due to their excellent biological activity. The activity of the complexes is described based on their mode and affinity of binding with DNA. ${ }^{9-11}$ Generally, DNA has been considered as a target molecule for a wide range of disease therapies such as anticancer and antiviral. Any disorder in gene expression may cause diseases and plays a secondary role in the outcome and severity of human diseases. ${ }^{12}$ Therefore, various metal-based drugs have been opted with improved pharmacological properties and aimed at different targets. Proteins play fundamental roles in sustaining life and are an integral part of origin, evolution, 
and metabolism. Being one of the most abundant proteins in blood constituent, serum albumin aids in the transportation of various molecules (ligands) including fatty acids, steroids and metal ions. ${ }^{13}$ Hence the binding of these molecules to serum albumins is taken under consideration in various fields. ${ }^{14}$ The homology of $76 \%$ in structures between the bovine serum albumin (BSA) and the human serum albumin (HSA) makes it a unique one for the researchers to be studied more comprehensively. ${ }^{15}$ Serum albumins are model globular proteins found abundant in plasma. Serum albumins exhibit a character of reversible binding with various molecules through hydrophobic, hydrophilic and electrostatic interactions. The binding of metal complexes with BSA can be detected by the decrease in intensity of the fluorescence emitted by one of the amino acid residues called tryptophan 212 , which is exposed outwards. It is expected that the ligand could bind into the two binding sites of BSA marked as site I and site II located in the hydrophobic cavities of subdomains IIA and IIIA, respectively. The binding of drug molecules to BSA on a particular site can be probed through various selective site markers. ${ }^{16}$ Serum albumin also binds metal ions, predominantly soft/intermediate metal ions at one or more of at least four proposed specific sites. Albumin binds hard metals in chelate form. For example, albumin scavenges hemin, the ferric state of heme, to avoid the formation of reactive oxygen species. Albumin binding affects the pharmacokinetics, trafficking and efficacy of metal-based therapeutics. ${ }^{17}$ Amino acids are small molecules capable of metal complexation via amino and carboxylate groups. ${ }^{18}$ It has been reported that transition metal complexes of amino acids could possess better fungicidal, anti-bacterial, antiviral and anti-tubercular activities. ${ }^{19}$ Hence, we herein report the synthesis of $\mathrm{Mn}$ (III) and $\mathrm{Fe}(\mathrm{III})$ complexes of L-tyrosine-based ligand and their interaction with CT-DNA/BSA using various spectral methods.

\section{Experimental}

All the chemicals utilized in this research work are of AR grade and also 99\% pure solvents are used. The ligands employed in our present investigation, viz. 9,10-phenanthrenequinone (Aldrich) and L-tyrosine (Loba Chemie) were purchased in pure form and used as such. CT-DNA and pBR322 DNA was purchased from Genei, Bengaluru, India. The protein bovine serum albumin (BSA) used in this experiment was purchased from Sigma whereas Tris buffer from HIMEDIA. Carlo Erba 1108 elemental analyzer was involved in analysing the elemental content $(\mathrm{C}, \mathrm{H}$, $\mathrm{N}$ ) of the ligand as well as its $\mathrm{Mn}$ (III) and $\mathrm{Fe}(\mathrm{III})$ complexes. The percentage of metal ions in the complexes were estimated as per the procedure given in the book. ${ }^{20}$ Nuclear magnetic study was performed on Bruker Advance DRX 300 FT-NMR spectrometer in $\mathrm{CDCl}_{3}$ solvent and the refer- ence material taken was TMS. JEOL DX-303 EI mass spectrometer and Bruker-Daltonics micro TOF-Q II mass spectrometer were used to record EI mass spectrum of the ligand and electrospray ionization mass spectra (ESI) of the complexes respectively. Vibrational spectral analysis of the ligand and its manganese and iron complexes were carried out on JASCO FT-IR/4100 Spectrometer, involving $\mathrm{KBr}$ disc method. The UV-vis spectra of both the synthesised complexes were taken in $200-800 \mathrm{~nm}$ wavelength range on a Perkin Elmer Lambda 35 spectrophotometer using the solvent DMSO. Hertz SG8-5HJ model Gouy magnetic balance was employed to study the magnetic susceptibility measurements by taking $\mathrm{CuSO}_{4} \cdot 5 \mathrm{H}_{2} \mathrm{O}$ as the calibrant. The molar conductivities of $\mathrm{MnL}$ and $\mathrm{FeL}$ were measured using Elico model SX 80 conductivity-bridge taking DMSO as solvent.

\section{1. Synthesis of Ligand}

About $2.08 \mathrm{~g}$ of 9,10-phenanthrenequinone (10.0 $\mathrm{mmol}$ ) dissolved in $50 \mathrm{~mL}$ of ethanol was taken in a twoneck flat bottomed flask. To this, $3.62 \mathrm{~g}$ of L-tyrosine (20.0 $\mathrm{mmol}$ ) dissolved in $20 \mathrm{~mL}$ of $1 \mathrm{M}$ sodium hydroxide was added. The reaction mixture was subjected to stirring for 10 hours to give a bright yellow colored precipitate of the Schiff base ligand (L). After washing the precipitate repeatedly with water and diethyl ether, it was then dried in vacuum over anhydrous calcium chloride. The dried product obtained (Scheme 1) was then characterized using IR, EIMS and ${ }^{13} \mathrm{C}$ NMR spectroscopic tools.

Yield: $75 \%$, m.p.: $178^{\circ} \mathrm{C}$, Anal. Found (\%): C, 71.84; H, 4.88; N, 5.20; Calc.: C, 71.90; H, 4.91; N, 5.22; EI-MS: $\mathrm{m} / z$, 534.46; IR $\left(\mathrm{KBr}, \mathrm{cm}^{-1}\right): v_{(\mathrm{C}=\mathrm{N})} 1673, v_{\text {asy }(\mathrm{COOH})}, 1589$, $v_{\mathrm{sy}(\mathrm{COOH})} 1450, v_{(\mathrm{OH})} 3205 ;{ }^{13} \mathrm{C} \mathrm{NMR}\left(\delta, \mathrm{ppm}\right.$ in $\left.\mathrm{CDCl}_{3}\right)$ : $163.19(\mathrm{C}=\mathrm{N}), 180.47(\mathrm{COOH})$.

\section{2. Synthesis of Metal Complexes}

$1.0 \mathrm{mmol}(0.58 \mathrm{~g})$ of finely powdered Schiff base ligand was dissolved in $20 \mathrm{~mL}$ ethanol. To this, $20 \mathrm{~mL}$ ethanolic solution of $1.0 \mathrm{mmol}$ metal salts (manganese(III) acetate $0.27 \mathrm{~g} /$ iron(III) chloride $0.40 \mathrm{~g}$ ) were added drop wise (Scheme 2). Then the mixture was subjected to stirring as well as refluxing at $50^{\circ} \mathrm{C}$ for 12 hours. The resulting homogenous solution was subjected to slow evaporation at room temperature and the product obtained was washed with ethanol and dried and stored in air tight container for further analysis.

MnL: Yield: 57\%; Brown color; Molecular weight: 623.51; Molecular formula $\mathrm{C}_{32} \mathrm{H}_{28} \mathrm{MnN}_{2} \mathrm{O}_{8}$; Anal. Found (\%): C, 61.57; H, 4.46; N, 4.82 and $\mathrm{Mn}, 8.76$. Calc.: C, 61.6; $\mathrm{H}, 4.5$; N, 4.9 and Mn, 8.81, ESI-MS: $\mathrm{m} / z$, 624.25; IR (KBr, $\left.\mathrm{cm}^{-1}\right): v_{(\mathrm{C}=\mathrm{N})} 1598, v_{\text {asy }\left(\mathrm{COO}^{-}\right)} 1512, v_{\mathrm{sy}\left(\mathrm{COO}^{-}\right)} 1435, v_{(\mathrm{M}-\mathrm{O})}$ 547, $v_{(\mathrm{M}-\mathrm{N})} 423 ; \Lambda_{\mathrm{m}}\left(\mathrm{S} \mathrm{mol}^{-1} \mathrm{~cm}^{2}\right)$ 51.78; $\mu_{\text {eff }}(\mathrm{BM}) 4.89$; UV-Vis (DMSO, $\mathrm{nm}$, transition): 280 (LMCT), 530 and 720 (d-d). 
FeL: Yield: 52\%; Green color; Molecular weight: 624.42; Molecular formula $\mathrm{C}_{32} \mathrm{H}_{28} \mathrm{FeN}_{2} \mathrm{O}_{8}$; Anal. Found (\%): C, 61.46; H, 4.44; N, 4.47 and Fe, 8.87. Calc.: C, 61.5; $\mathrm{H}, 4.5 ; \mathrm{N}, 4.5$ and $\mathrm{Fe}, 8.94$, ESI-MS: $\mathrm{m} / \mathrm{z}, 625.91$; IR $(\mathrm{KBr}$, $\left.\mathrm{cm}^{-1}\right): v_{(\mathrm{C}=\mathrm{N})} 1611, v_{\text {asy }\left(\mathrm{COO}^{-}\right)} 1513, v_{\mathrm{sy}\left(\mathrm{COO}^{-}\right)} 1402, v_{(\mathrm{M}-\mathrm{O})}$ 528, $v_{(\mathrm{M}-\mathrm{N})}, 435 ; \Lambda_{\mathrm{m}}\left(\mathrm{S} \mathrm{mol}^{-1} \mathrm{~cm}^{2}\right)$ 51.56; $\mu_{\text {eff }}(\mathrm{BM}) 5.93$; UV-Vis (DMSO, nm, transition): 275 (LMCT), 525 and 670 (d-d).

\section{Results and Discussion}

\section{1. Scheme}

The schematic representation of the Schiff Base ligand synthesized from the effective condensation of 9,10-phenanthrenequinone and L-tyrosine is shown in Scheme 1 and Scheme 2 represents the complexation of the ligand with $\mathrm{Mn}(\mathrm{III}) / \mathrm{Fe}(\mathrm{III})$ ions.

\section{2. FTIR Spectra}

The FTIR spectrum of the ligand L (Fig. S1a) exhibit the imine stretching $v(-\mathrm{C}=\mathrm{N})$ vibration at $1673 \mathrm{~cm}^{-1}$. The peaks due to $(\mathrm{COOH})$ asymmetric stretching and $(\mathrm{COOH})$ symmetric stretching vibration are observed in the regions of $1589 \mathrm{~cm}^{-1}$ and $1450 \mathrm{~cm}^{-1}$ respectively. The less intense and weak band at $3570 \mathrm{~cm}^{-1}$ corresponds to phenolic $-\mathrm{OH}$ stretching. In the vibrational spectra of complexes (Fig S1b and $\mathrm{S} 1 \mathrm{c})$, the imino $(\mathrm{C}=\mathrm{N})$ stretching frequency has been shifted to lower frequency regions 1598 and $1611 \mathrm{~cm}^{-1}$, respectively, when compared to the imino stretching frequency of ligand $\left(1673 \mathrm{~cm}^{-1}\right)$. This indicates the coordination of nitrogens in the imino group to the metal ions. ${ }^{21}$ Moreover, the asymmetric stretching and the symmetric stretching vibrations of $\mathrm{COO}^{-}$group has been shifted down to $1512 \mathrm{~cm}^{-1}, 1513 \mathrm{~cm}^{-1}$ and $1435 \mathrm{~cm}^{-1}, 1402 \mathrm{~cm}^{-1}$, respectively, which confirms the bonding of the metal ions by the carboxylato oxygen atom. ${ }^{22}$ This is further support-

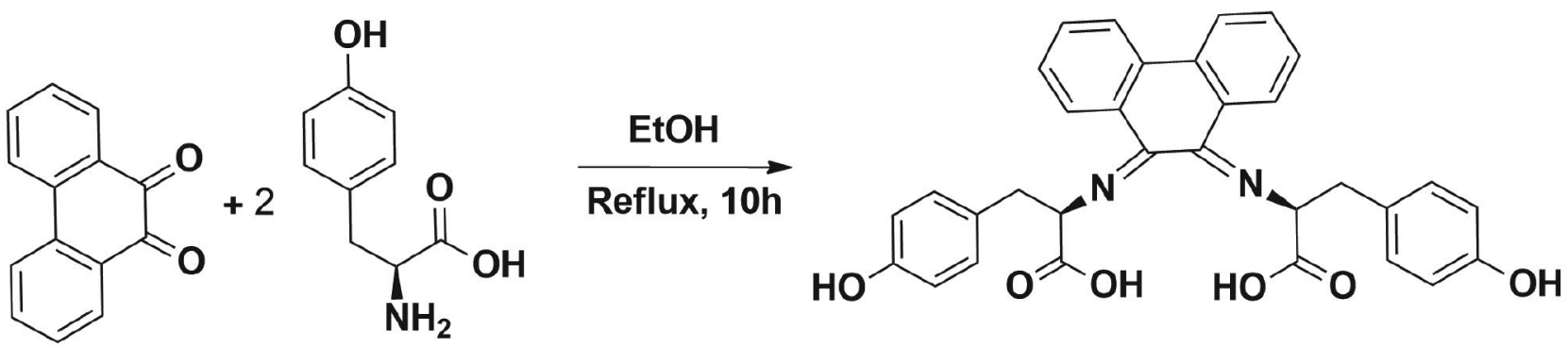

Scheme 1: Synthesis of Schiff base ligand<smiles>O=C(O)[C@H](Cc1ccc(O)cc1)N=C1C(=N[C@H](Cc2ccc(O)cc2)C(=O)O)c2ccccc2-c2ccccc21</smiles>
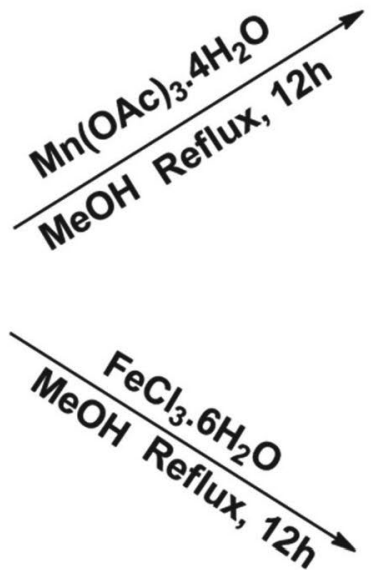

Scheme 2: Synthesis of $\mathrm{Mn}(\mathrm{III}) / \mathrm{Fe}(\mathrm{III})$ complexes

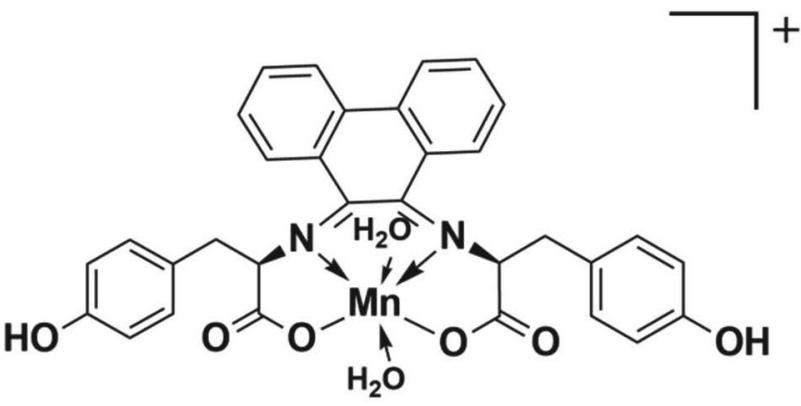

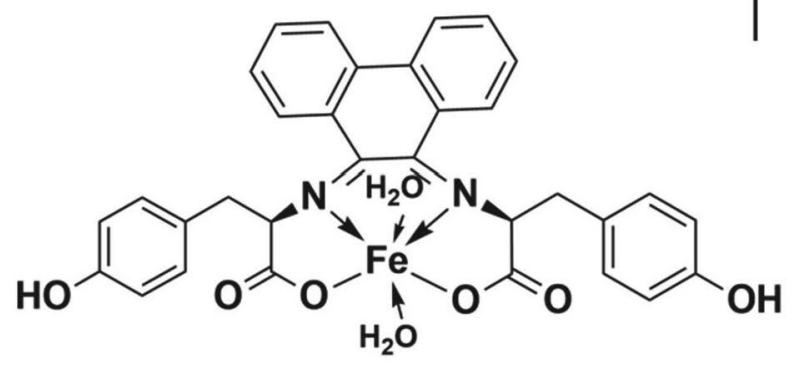


ed by the presence of $\mathrm{Mn}-\mathrm{N}, \mathrm{Fe}-\mathrm{N}$ and $\mathrm{Mn}-\mathrm{O}, \mathrm{Fe}-\mathrm{O}$ bands at $423 \mathrm{~cm}^{-1}, 435 \mathrm{~cm}^{-1}$ and $547 \mathrm{~cm}^{-1}, 528 \mathrm{~cm}^{-1}$, respectively. ${ }^{23}$ The $-\mathrm{OH}$ stretching vibrations exhibits broad band at $3423 \mathrm{~cm}^{-1}$ and $3200 \mathrm{~cm}^{-1}$ for the $\mathrm{MnL}$ and $\mathrm{FeL}$ complexes, respectively. The peaks around $750 \mathrm{~cm}^{-1}$ and $650 \mathrm{~cm}^{-1}$ correspond to $\rho_{\mathrm{r}}\left(\mathrm{H}_{2} \mathrm{O}\right)$ and $\rho_{\mathrm{w}}\left(\mathrm{H}_{2} \mathrm{O}\right)$ of coordinated water molecules, respectively.

\section{3. ${ }^{13} \mathrm{C}$ NMR Spectra}

The ${ }^{13} \mathrm{C}$ NMR spectrum of the ligand L (Fig S2) shows a signal at $\delta 155.98$ assigned to two $-\mathrm{OH}$ attached carbons. The signal at $\delta 36.13$ is assigned to $-\mathrm{CH}_{2}$ carbons present in between azomethine groups. The signal for the methane carbon of L-tyrosine appears at $\delta 67.10$. The signals in the range $\delta 114.12-136.16$ are due to aromatic carbon $^{24}$ atoms of L-tyrosine as well as 9,10-phenanthrenequinone. The signal at $\delta 163.19$ corresponds to the two azomethine carbons. ${ }^{25}$ The signal at $\delta 180.47$ is due to the two carboxylate carbons.

\section{4. Mass Spectra}

The EI mass spectrum of ligand L (Fig S3a) posses a molecular ion $\left(\mathrm{M}^{+}\right)$peak at $m / z=534$ which is meant to the molecular weight of the ligand. The peaks at $\mathrm{m} / z=485$, $440,383,305,253,236,204,181,154,136,108,78$ and 58 corresponds to various fragments $\mathrm{C}_{31} \mathrm{H}_{23} \mathrm{~N}_{2} \mathrm{O}_{4}$, $\mathrm{C}_{26} \mathrm{H}_{20} \mathrm{~N}_{2} \mathrm{O}_{5}, \quad \mathrm{C}_{20} \mathrm{H}_{18} \mathrm{~N}_{2} \mathrm{O}_{6}, \mathrm{C}_{18} \mathrm{H}_{13} \mathrm{~N}_{2} \mathrm{O}_{3}, \quad \mathrm{C}_{16} \mathrm{H}_{13} \mathrm{NO}_{2}$, $\mathrm{C}_{15} \mathrm{H}_{9} \mathrm{NO}_{2}, \quad \mathrm{C}_{14} \mathrm{H}_{8} \mathrm{~N}_{2}, \quad \mathrm{C}_{12} \mathrm{H}_{9} \mathrm{NO}, \mathrm{C}_{12} \mathrm{H}_{10}, \mathrm{C}_{7} \mathrm{H}_{6} \mathrm{NO}_{2}$, $\mathrm{C}_{7} \mathrm{H}_{7} \mathrm{O}, \mathrm{C}_{6} \mathrm{H}_{4}$ and $\mathrm{C}_{2} \mathrm{H}_{2} \mathrm{O}_{2}$, respectively, which confirms the structure of the ligand. The structure of the complexes was corroborated with ESI-MS studies. The ESI mass spectra of the complexes exhibit the molecular ion peak which is in correct accordance with their molecular weights. The various other peaks in the spectra correspond to different fragments of the complexes. In the spectrum of MnL (Fig S3b), the molecular ion peak is observed at $\mathrm{m} / z=624.25$ and for the complex FeL (Fig S3c), the molecular ion peak is obtained at $\mathrm{m} / z=625.91$ which are in correct coherency with the molecular weight of the complexes. Therefore, the mass spectral analysis substantiates well with the proposed chemical structure of the complexes $\mathrm{MnL}$ and FeL.

\section{5. Electronic Spectra, Molar Conductance, and Magnetic Measurements}

The UV-Vis spectrum of MnL (Fig 1a) exhibit ligand field absorption at $280 \mathrm{~nm}$ and two d-d bands at $530 \mathrm{~nm}$ and $720 \mathrm{~nm}$ corresponding to ${ }^{5} \mathrm{~B}_{1 \mathrm{~g}} \rightarrow{ }^{5} \mathrm{E}_{\mathrm{g}}$ and ${ }^{5} \mathrm{~B}_{1 \mathrm{~g}} \rightarrow{ }^{5} \mathrm{~B}_{2 \mathrm{~g}}$ transitions, respectively. Normally these two weak transitions are expected for tetragonally distorted octahedral MnL complex. ${ }^{26}$ The electronic spectra of FeL (Fig 1b) complex show three absorption maxima at $670 \mathrm{~nm}, 525$ $\mathrm{nm}$, and $275 \mathrm{~nm}$. The transitions corresponding to the aforesaid absorption bands are ${ }^{6} \mathrm{~A}_{1 \mathrm{~g}}(\mathrm{~S}) \rightarrow{ }^{4} \mathrm{~T}_{1 \mathrm{~g}}(\mathrm{G}),{ }^{6} \mathrm{~A}_{1 \mathrm{~g}}(\mathrm{~S}) \rightarrow$
${ }^{4} \mathrm{~T}_{2 \mathrm{~g}}(\mathrm{G})$ and ${ }^{6} \mathrm{~A}_{1 \mathrm{~g}}(\mathrm{~S}) \rightarrow{ }^{4} \mathrm{E}_{\mathrm{g}}$ respectively, suggesting the octahedral geometry for FeL complex. ${ }^{27}$ The magnetic moment values of 4.86 $\mathrm{BM}$ and 5.91 $\mathrm{BM}$ for $\mathrm{MnL}$ and FeL, respectively, further confirms the octahedral geometry. ${ }^{28}$ The values obtained for molar conductance (51.78 and 51.56) of $\mathrm{MnL}$ and FeL complexes, respectively, reveals that the complexes are 1:1 electrolytes. ${ }^{29}$


Fig. 1 (a) Electronic spectra of MnL complex (b) FeL complex

\section{6. DNA Binding Studies}

\section{6. 1. Absorption Spectral Studies}

The binding ability of the MnL and FeL complexes in DMSO solutions with CT-DNA were studied by measuring their effects on the absorption spectral method. In this method, the titrations were done at fixed complex concentration against different concentrations of DNA. If only could the complexes bind intercalatively to DNA helix, it shows hypochromism and also bathochromism. Since there exists a stacking interaction of an aromatic chromophore between the base pairs of nucleic acid, hy- 
pochromism arise ${ }^{30}$ whereas the bathochromic shift is a characteristic of coupling of $\pi^{*}$ orbital of the complexes with the $\pi$ orbital of the DNA nucleotide pairs which in turn causes decrease of the $\pi \rightarrow \pi^{*}$ transition energy. ${ }^{31} \mathrm{Hy}-$ pochromism is generally a measure of the extend of intercalative mode of binding. ${ }^{32}$ An aqueous solution of the complexes showed intra-ligand charge transition bands at $276 \mathrm{~nm}(\mathrm{MnL})$ and $264 \mathrm{~nm}(\mathrm{FeL})$ which resulted in hypochromism on addition of increasing concentration of CT-DNA (Fig S4a and S4b) from which the binding constants $K_{\mathrm{b}}$ of the complexes were evaluated. The intrinsic equilibrium binding constant $K_{\mathrm{b}}$ was found to be $1.22 \times$ $10^{5} \mathrm{M}^{-1}$ and $1.56 \times 10^{5} \mathrm{M}^{-1}$ for $\mathrm{MnL}$ and FeL complexes, respectively, which is in compliance with the observed trend in hypochromism. These experimentations conclude that both the complexes could interact through intercalation with DNA.

\section{6. 2. EB Fluorescence Displacement Assay}

A competitive binding titrations using ethidium bromide have been performed to substantiate the above results. Being a non-fluorescent compound in Tris-buffer, ethidium bromide (EB) shows fluorescence when combined with DNA, because of its strong intercalation between the nucleotides of DNA. ${ }^{33}$ It is reported that the emission of DNA pretreated with EB is being quenched by some complexes resulting in the reduction of emission intensity. On addition of the complexes MnL and FeL to EBDNA, the fluorescence intensity at $615 \mathrm{~nm}$ was decreased with increasing the concentration of the complexes without any shift in the position of emission maxima ${ }^{34}$ as seen in (Fig $2 \mathrm{a}$ and $2 \mathrm{~b}$ ). From the classical Stern-Volmer equation, the apparent binding constant values $\left(K_{\text {app }}\right)$ for the complexes $\mathrm{MnL}$ and FeL were calculated and it is found to be $4.8 \times 10^{6} \mathrm{M}^{-1}$ and $12.3 \times 10^{6} \mathrm{M}^{-1}$. From the observed results, it may be concluded that both the complexes interact with CT-DNA via intercalative mode.

\section{6. 3 Viscosity Experiments}

Viscosity experiments provide additional information regarding the intercalative nature of complexes between the nucleotide pairs of CT-DNA (Fig 3). The increase in complex concentration enhances the DNA viscosity as the base pairs of DNA get separated at its intercalation sites causing increase in the overall DNA length. ${ }^{35}$ The viscosity of the DNA increases gradually with increase in complex concentration. These results indicate that both the complexes under study can intercalate the adjacent DNA base pairs, causing an expansion in the helix, and thus enhance the viscosity of DNA. Thus, the intercalative binding of the

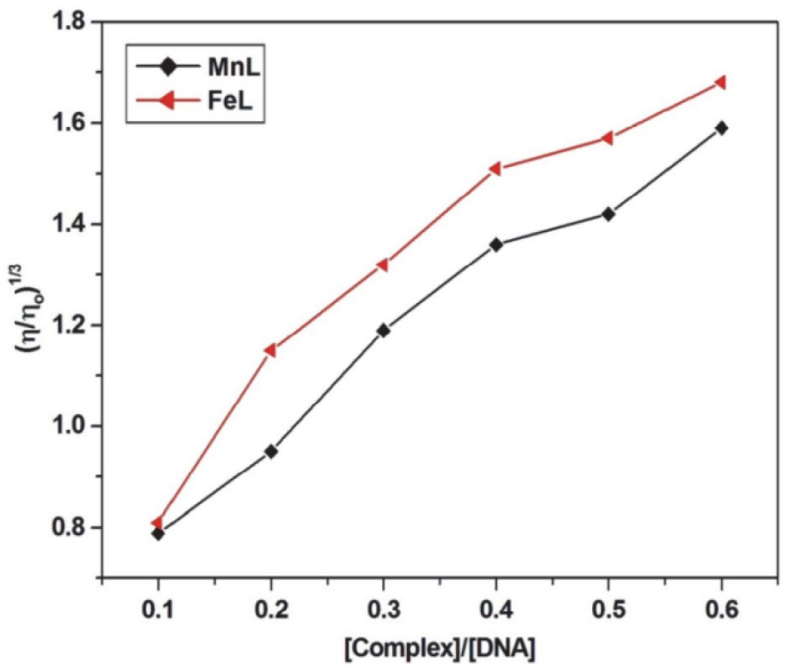

Fig. 3: Effect of increasing amounts of $\mathrm{MnL}$ and $\mathrm{FeL}$ on the relative viscosities of CT-DNA at room temperature in $5 \mathrm{mM}$ Tris- $\mathrm{HCl}$ buffer
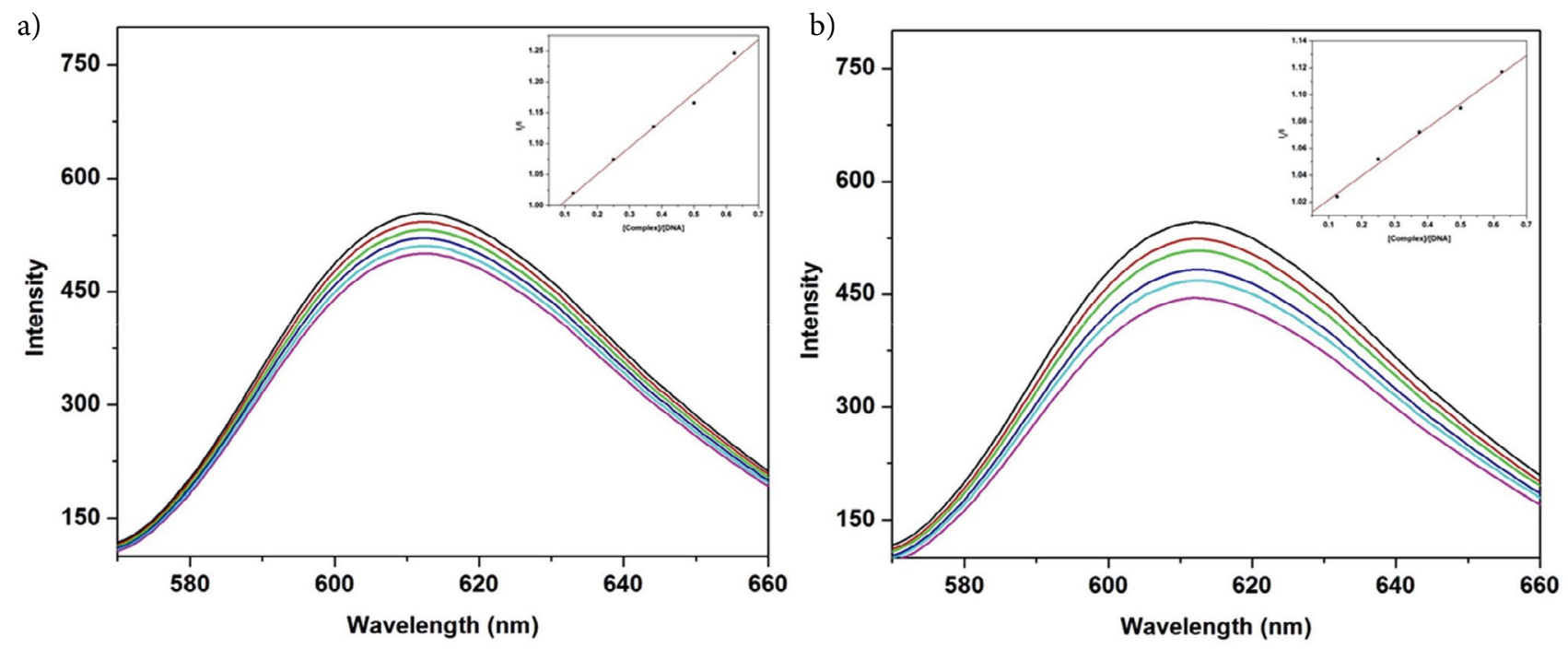

Fig. 2: Emission spectrum of EB bound to DNA in the presence of complexes ([EB] $=3.3 \mu \mathrm{M},[\mathrm{DNA}]=40 \mu \mathrm{M}$, [complex] $\left.=0-30 \mu \mathrm{M}, \lambda_{\mathrm{ex}}=430 \mathrm{~nm}\right)$. Inset shows the plots of emission intensity $I_{\mathrm{o}} / I$ vs [DNA] / [complex]. (a) Emission spectra of MnL complex (b) Emission spectra of FeL complex 
complexes to CT-DNA is determined as established through absorption and fluorescence measurements.

\section{7. DNA Cleavage Analysis}

The cleavage efficiency of the complexes was studied on pBR322 plasmid DNA using agarose gel electrophoresis so as to identify the conformational changes of the DNA. When electrophoresis is performed on circular plasmid pBR322 DNA (Fig. 4), there occurs a rapid migration for the supercoiled SC form (Form I). The super coiled form of the DNA was relaxed to slow moving open circular OC form (Form II) in the presence of oxidant $\mathrm{H}_{2} \mathrm{O}_{2}$ which indicates that one strand is being cleaved. ${ }^{36}$ Both the $\mathrm{MnL}$ and $\mathrm{FeL}$ complexes possess the tendency to cleave the DNA from SC form to OC form on various concentrations $(10,20$ and 30 $\mu \mathrm{g})$. From the Figure 4 it is observed that no cleavage occurred in the case of control DNA (lane 1) and control DNA/ $\mathrm{H}_{2} \mathrm{O}_{2}$ (lane 2). The complex MnL shows no cleavage at $10 \mu \mathrm{g}$ (lane 3) but partial cleavage is observed at $20 \mu \mathrm{g}$ (lane 4) and $30 \mu \mathrm{g}$ (lane 5) from SC form (Form I) to OC (Form II) in the presence of $\mathrm{H}_{2} \mathrm{O}_{2}$. Similarly, the complex FeL does not cleave the DNA at $10 \mu \mathrm{g}$ (lane 6) but in the presence of the oxidant it exhibits partial cleavage from SC form (Form I) to OC (Form II) at $20 \mu \mathrm{g}$ (lane 7) and $30 \mu \mathrm{g}$ (lane 8). An effective cleavage is visualized as the concentration of the complexes increases. Both the $\mathrm{MnL}$ and FeL complexes could cleave DNA more effectively in the presence of an oxidant $\left(\mathrm{H}_{2} \mathrm{O}_{2}\right)$ which may be attributed to the involvement of hydroxyl free radicals. In oxidative cleavage, the hydroxyl free radicals formed oxidize the deoxyribose moiety and further hydrolytic cleavage of sugar phosphate back bone occurs. ${ }^{37}$

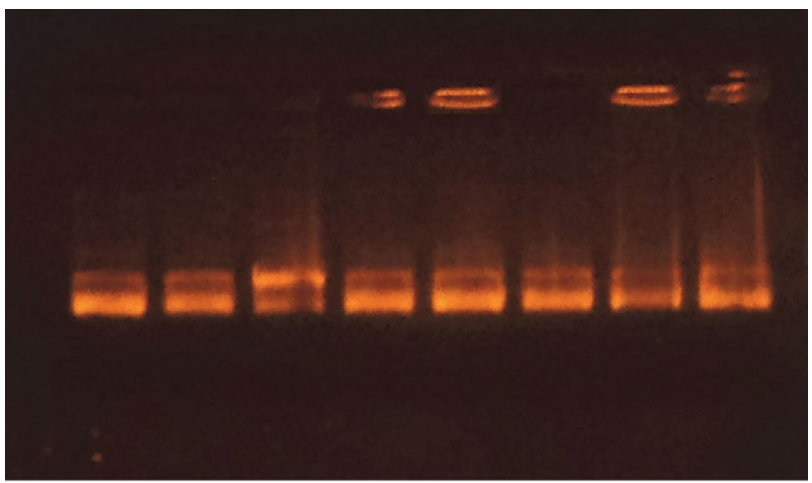

Fig. 4: DNA cleavage analysis. 1st well- Control only pBR322; 2nd well- pBR322 $+\mathrm{H}_{2} \mathrm{O}_{2}$ and Buffer; 3rd well- Sample $(\mathrm{MnL})-10 \mu \mathrm{g}$; 4th well- Sample (MnL)-20 $\mu$; 5th well-sample (MnL)-30 $\mu$ g; 6th wellsample (FeL)-10 $\mu$; 7 th well- sample (FeL)-20 $\mu$ g; 8 th well- sample (FeL)-30 $\mu \mathrm{g}$

\section{8. BSA Binding Studies}

\section{8. 1 Fluorescence Spectroscopy}

The intrinsic BSA fluorescence at $340 \mathrm{~nm}$ due to tryptophan moiety ${ }^{38}$ is quenched on addition of drug mol- ecules. The mechanistic process involved in quenching is categorized to be static or dynamic. The molecular collisions results in dynamic quenching while static quenching arises as a result of complex formation in groud-state between the protein and the quencher. Dynamic quenching values are found to increase along with temperature whereas the static quenching constants decrease with temperature. ${ }^{39}$ This quenching mechanism can be explored from Stern-Volmer equation. ${ }^{40}$

$$
\frac{F_{0}}{F}=1+K_{\mathrm{sv}}[\mathrm{Q}]=1+K_{\mathrm{q}} \tau_{0}[\mathrm{Q}]
$$

The emission maxima in-absentia and presence of quencher molecules are denoted as $F_{0}$ and $F$, respectively. $K_{\mathrm{sv}}$ being Stern-Volmer quenching constant and the quencher concentration is designated as [Q] with $\tau_{0}$, the mean life time of protein and for BSA it is found to be $10^{-8} \mathrm{~s}{ }^{41} K_{\mathrm{q}}$ is

a)

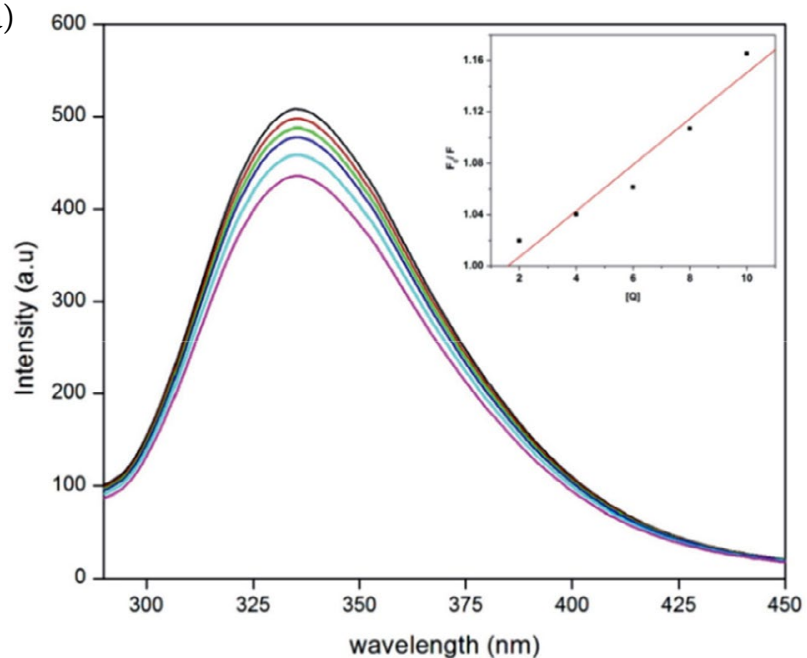

b)

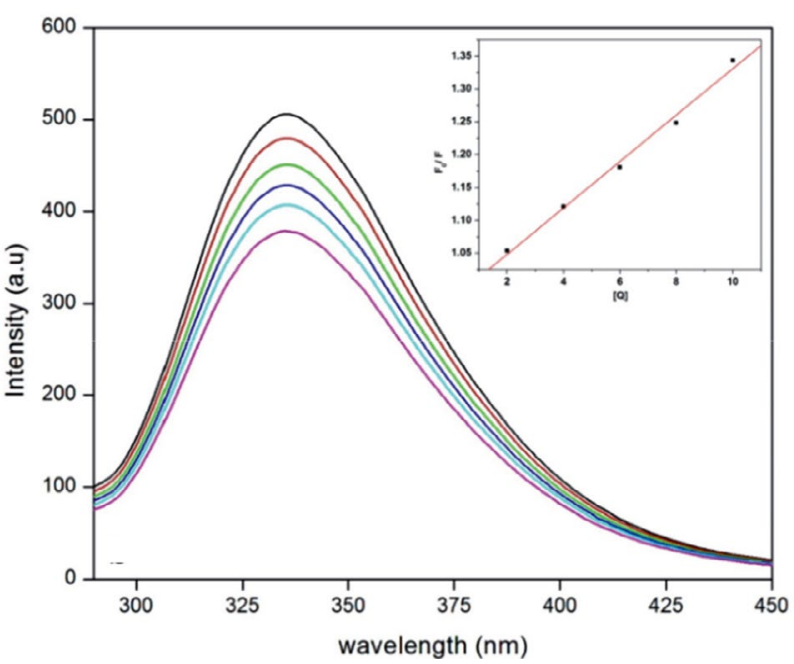

Fig. 5: Emission spectra of BSA in the presence of various concentrations of metal complexes in DMSO $(T=298 \mathrm{~K}), c(\mathrm{BSA})=2.0 \times$ $10^{-6} \mathrm{~mol} \mathrm{~L}^{-1}, c$ (Metal complex) $=2,4,6,8,10 \times 10^{-6} \mathrm{~mol} \mathrm{~L}^{-1}$. Insert: Stern-Volmer plot for quenching of BSA by metal complexes (a) Emission spectra of BSA with MnL complex (b) Emission spectra of BSA with FeL complex 
the quenching rate constant of the protein and it is equal to $K_{\mathrm{sv}} / \tau_{0}$. The $K_{\mathrm{sv}}$ values are obtained from the slope of linear fitting plots $F_{0} / F v s[\mathrm{Q}]$. The Stern-Volmer plots for MnL and FeL complexes at three different temperatures $298 \mathrm{~K}$, $304 \mathrm{~K}$ and $310 \mathrm{~K}$ are provided in Figs. 5, S5 and S6 and their $K_{\mathrm{q}}$ values are presented in Table 1 . The results conclude that Stern-Volmer quenching constants $\left(K_{\mathrm{sv}}\right)$ decreases with increasing temperature. Also, it was found that the $K_{\mathrm{q}}$ values are greater than $2.0 \times 10^{10} \mathrm{~L} \mathrm{~mol}^{-1} \mathrm{~s}^{-1}$ and this value is attributed to the maximum scattering collision quenching constant of various quenchers for dynamic quenching. ${ }^{42}$ This exposes that the BSA quenching by $\mathrm{MnL}$ and $\mathrm{FeL}$ is due to ground-state complex formation i.e., static and not dynamic quenching.

Table 1: $K_{\mathrm{sv}}$ and $K_{\mathrm{q}}$ values of $\mathrm{MnL}$ and FeL complexes

\begin{tabular}{lccc}
\hline Complexes & $\boldsymbol{T}(\mathbf{K})$ & $\begin{array}{c}\boldsymbol{K}_{\text {sv }} \\
\left(\times \mathbf{1 0} \mathbf{L} \mathbf{~} \mathbf{m o l}^{-\mathbf{1}}\right)\end{array}$ & $\begin{array}{c}\boldsymbol{K}_{\mathbf{q}} \\
\left(\times \mathbf{1 0}^{\mathbf{1 2}} \mathbf{L} \mathbf{~} \mathbf{~ o l}^{-\mathbf{1}} \mathbf{s}^{-\mathbf{1}}\right)\end{array}$ \\
\hline $\mathrm{MnL}$ & 298 & 2.10 & 2.10 \\
& 304 & 1.39 & 1.39 \\
& 310 & 1.07 & 1.07 \\
\hline $\mathrm{FeL}$ & 298 & 3.53 & 3.53 \\
& 304 & 2.69 & 2.69 \\
& 310 & 2.29 & 2.29 \\
\hline
\end{tabular}

\section{8. 2. Absorption Spectroscopy}

Ground state interaction of MnL and FeL with BSA is further proved by UV-vis absorption spectra. The absorption spectra were recorded both for the BSA and BSA$\mathrm{MnL} / \mathrm{FeL}$ system in the range of $200-350 \mathrm{~nm}$ (Fig. 6). A bathochromic shift occurs at the absorption maxima compared to that of BSA which confirms the static quenching mechanism. ${ }^{43}$

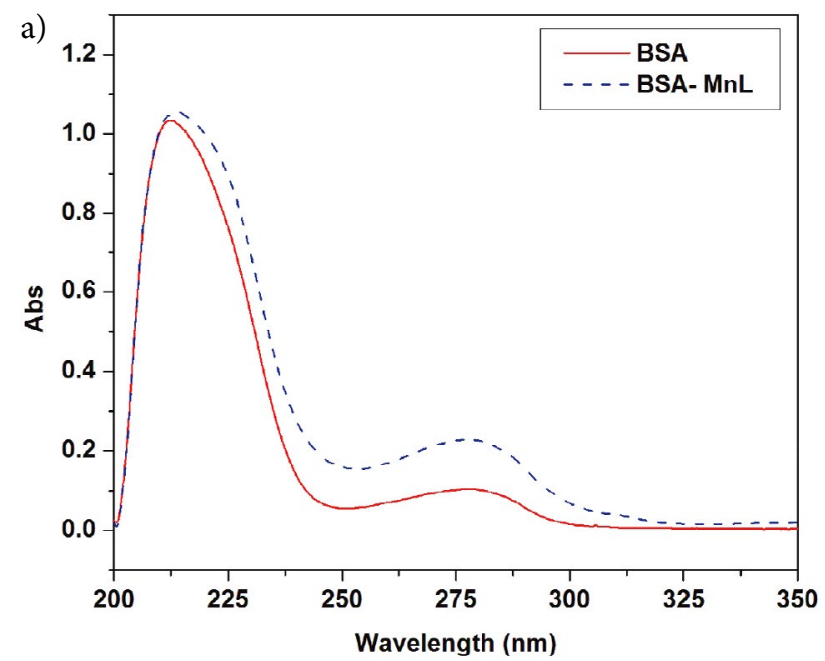

\section{8. 3. Analysis of Binding Constants and Binding Sites}

From the binding of complexes $\mathrm{MnL}$ and FeL with BSA, the binding constants $\left(K_{\mathrm{b}}\right)$ and the binding sites $(n)$ can be calculated from the following equation. ${ }^{44}$

$$
\log \left(\frac{F_{0}-F}{F}\right)=\log K_{b}+n \log [Q]
$$

The values of $K_{\mathrm{b}}$ and $n$ are obtained (Table 2) from the intercepts and slopes of the linear fitting plots of $\log F_{0}$ - F/F vs $\log [\mathrm{Q}]$ at $298 \mathrm{~K}$ are displayed in Fig. 7 for MnL and FeL complexes, respectively. Similarly, the plots for BSA-MnL complex at $304 \mathrm{~K}$ and $310 \mathrm{~K}$ and for BSA-FeL complex at $304 \mathrm{~K}$ and $310 \mathrm{~K}$ are shown in Figs. S7 and S8, respectively. The binding site values approximated to 1 reveals the existence of only one binding site in BSA where the complexes could bind. The BSA molecule possess two tryptophan residues, ie., Trp-134 in sub-domain IA and Trp-212 in hydrophobic sub-domain IIA. Any molecules which bind to sub-domain IIA can result in conformational changes. ${ }^{45}$ These results confirm that the complexes could fit into the hydrophobic pocket in sub-domain IIA.

Table 2: Binding constant $\left(K_{\mathrm{b}}\right)$ and Binding site $(n)$ values of $\mathrm{MnL}$ and FeL complexes

\begin{tabular}{lccc}
\hline Complexes & $\boldsymbol{T}(\mathbf{K})$ & $\begin{array}{c}\text { Binding constant } \\
\left(\mathbf{1 0}^{\mathbf{4}} \mathbf{~} \mathbf{~ m o l}^{-\mathbf{1}}\right)\end{array}$ & $\begin{array}{c}\text { Binding } \\
\text { site }\end{array}$ \\
\hline MnL & 298 & 5.72 & 1.31 \\
& 304 & 4.95 & 1.16 \\
& 310 & 4.37 & 1.06 \\
\hline FeL & 298 & 5.17 & 1.12 \\
& 304 & 4.71 & 1.05 \\
& 310 & 4.66 & 1.02 \\
\hline
\end{tabular}

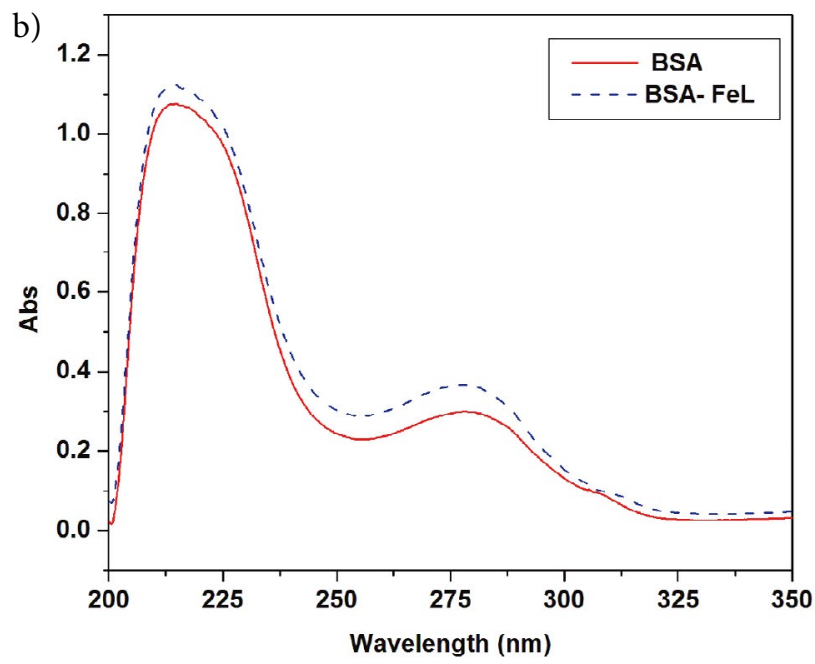

Fig. 6: UV-Vis absorption spectra of BSA and BSA-Metal complex solutions: $c(\mathrm{BSA})=c$ (Metal complex $)=2 \times 10^{-6} \mathrm{~mol} \mathrm{~L}^{-1}$. (a) BSA-MnL solution (b) BSA-FeL solutions 

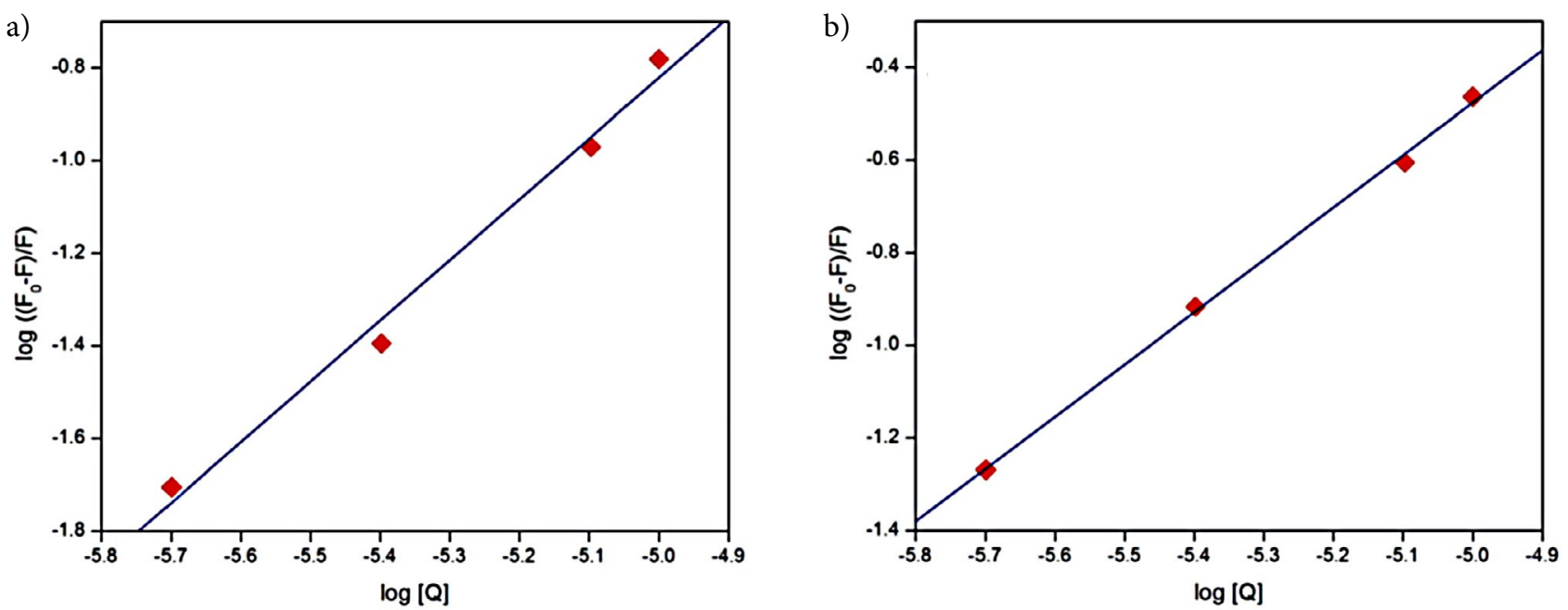

Fig. 7: Double logarithm plot for BSA-metal complexes at $298 \mathrm{~K}$ (a) Double logarithm plot for BSA-MnL (b) Double logarithm plot for BSA-FeL

\section{8. 4 Thermodynamic Parameters}

The interactions between the complexes and BSA could be hydrophobic, hydrogen bonds, van der Waals forces and electrostatic interactions. ${ }^{46}$ It can be found out from the thermodynamic parameters such as enthalpy $(\Delta H)$ and entropy $(\Delta S)$. The thermodynamic parameters were investigated at $298 \mathrm{~K}, 303 \mathrm{~K}$ and $310 \mathrm{~K}$ and the result shows no structural degradation was observed in BSA. The values for $\Delta H$ and $\Delta S$ can be obtained from the following van't Hoff equation.

$$
\ln k=\frac{-\Delta H}{R T}+\frac{\Delta S}{R}
$$

The free energy changes can be obtained from,

$$
\Delta G=-R T \ln K
$$

The $\Delta H$ and $\Delta S$ values can be obtained from the slopes and ordinates of linear fitting plots of $\ln K v s 1 / T$

a)

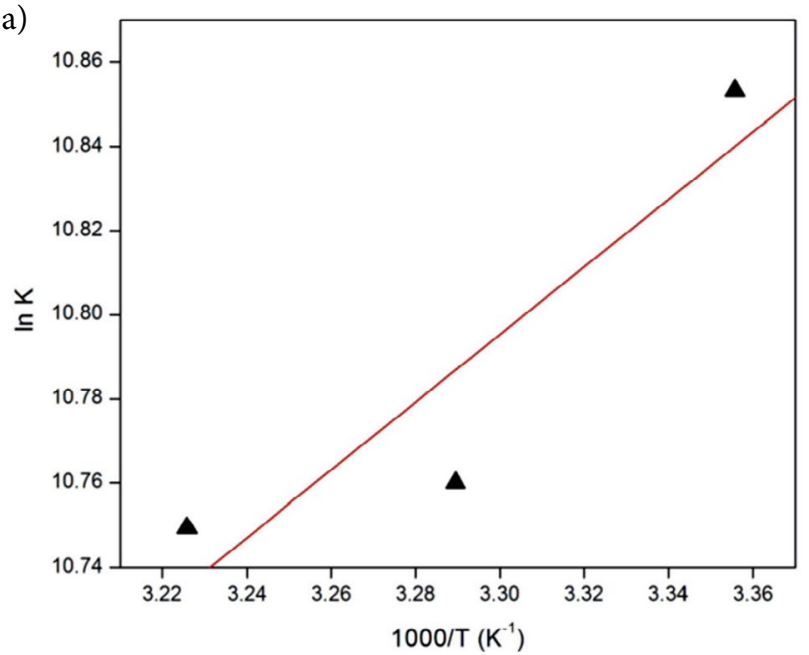

(Fig. 8). The positive values of $\Delta H$ and $\Delta S$ are attributed to hydrophobic interactions. The $\Delta H$ and $\Delta S$ values being negative shows the existence of hydrogen bonding and van der Waals forces, very low positive or negative $\Delta H$ value and positive $\Delta S$ values are attributed to electrostatic interactions. ${ }^{47}$ From the thermodynamic parameters (Table 3 ), the negative enthalpy $(\Delta H)$ and positive entropy $(\Delta S)$ values ascertains that electrostatic interactions played an important role between BSA and $\mathrm{MnL} / \mathrm{FeL}$. The negative $\Delta G$ values calculated, proves the spontaneous binding process.

\section{8. 5 Energy Transfer Between Metal Complexes and BSA}

The binding of metal complexes to BSA becomes effective only when there is considerable transfer of energy between the donor and the acceptor which can be calculated from Forster's resonance energy transfer theory. ${ }^{48}$ For an effective energy transfer, the following conditions must be



Fig. 8: van't Hoff plot for the interaction of BSA with (a) MnL complex (b) FeL complex 
Table 3: Thermodynamic parameters of the binding interaction of metal complexes with BSA

\begin{tabular}{|c|c|c|c|c|}
\hline Complexes & $T(\mathrm{~K})$ & $\Delta H\left(\mathrm{~kJ} \mathrm{~mol}^{-1}\right)$ & $\Delta S\left(\mathrm{~J} \mathrm{~mol}^{-1} \mathrm{~K}^{-1}\right)$ & $\Delta G\left(\mathrm{~kJ} \mathrm{~mol}^{-1}\right)$ \\
\hline \multirow[t]{3}{*}{$\mathrm{MnL}$} & 298 & -17.23 & 33.22 & -27.14 \\
\hline & 304 & & & -27.33 \\
\hline & 310 & & & -27.54 \\
\hline \multirow[t]{3}{*}{$\mathrm{FeL}$} & 298 & -6.68 & 67.72 & -26.89 \\
\hline & 304 & & & -27.20 \\
\hline & 310 & & & -27.71 \\
\hline
\end{tabular}

satisfied: a) the donor must be a fluorescent in nature b) there must be a spectral overlap between the emission of donor and the absorption of acceptor; c) the donor-acceptor distance should be less than $8 \mathrm{~nm}$. From the following equation, the efficiency of energy transfer can be calculated. ${ }^{49}$

$$
E=1-\frac{F}{F_{0}}=\frac{R_{0}^{6}}{R_{0}^{6}+r^{6}}
$$

Where $r$ is the donor-acceptor distance, $R_{0}$ is the critical distance at which $50 \%$ energy transfer occurs and is given by, ${ }^{50}$

$$
R_{0}{ }^{6}=8.8 \times 10^{-25} K^{2} n^{-4} \Phi J
$$

$K^{2}$ the orientation factor whose value is found to be $2 / 3$ for random alignment in fluid medium; $n$ being the average refractive index of the medium in the wavelength region of significant spectral overlap $(n=1.336)$; $\Phi$ is denoted for the quantum efficiency for emission of donor and for BSA it is $0.15 ;{ }^{51} \mathrm{~J}$ is found to be the overlap integral amid the emission and absorbance spectra of donor/acceptor which is calculated as follows

$$
J=\frac{\sum \varepsilon(\lambda) F(\lambda) \lambda^{4} \Delta \lambda}{\sum F(\lambda) \Delta \lambda}
$$

$F(\lambda)$ is represented for corrected donor fluorescence intensity in wavelength range $\lambda, \varepsilon(\lambda)$ is the acceptor's ab-

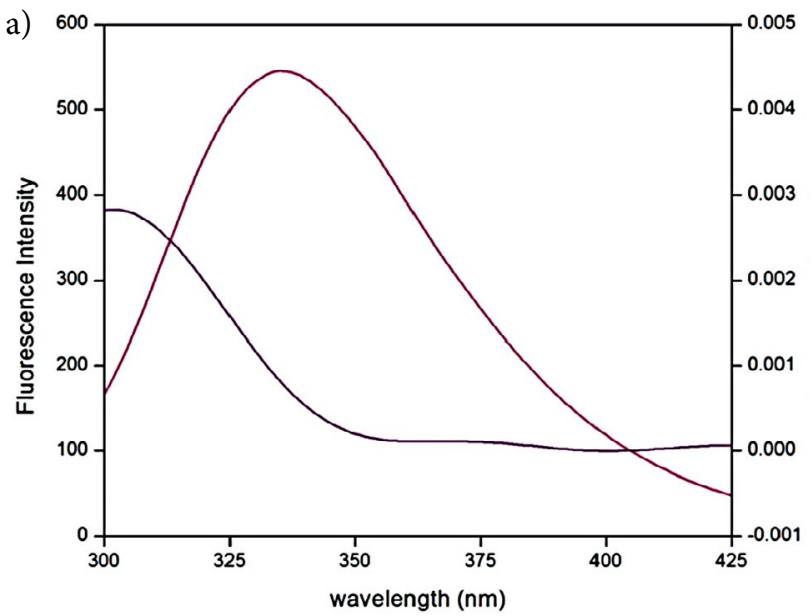

sorptivity at wavelength $\lambda$. The spectral overlap between the emission of BSA and absorption of $\mathrm{MnL}$ and FeL are shown in Fig. 9 along with the energy transfer parameters given in Table 4. The donor-acceptor distance $(r)$ is calculated to be lesser than $8 \mathrm{~nm},{ }^{52}$ ascribing the occurrence of transfer energy from BSA to metal complexes with high possibility.

Table 4: Energy transfer parameters for the interaction of metal complexes with BSA

\begin{tabular}{lcccc}
\hline Complexes & $\boldsymbol{J}\left(\mathbf{c m}^{\mathbf{3}} \mathbf{L} \mathbf{~ m o l}^{-1}\right)$ & $\boldsymbol{R}_{\mathbf{0}}(\mathbf{n m})$ & $\boldsymbol{E}$ & $\boldsymbol{r}(\mathbf{n m})$ \\
\hline $\mathrm{MnL}$ & $6.47 \times 10^{-14}$ & 3.44 & 0.037 & 5.91 \\
$\mathrm{FeL}$ & $2.27 \times 10^{-15}$ & 1.96 & 0.051 & 3.20 \\
\hline
\end{tabular}

\section{9. Molecular Docking Studies of Human DNA Topoisomerase I and BSA}

The molecular docking system can add normal medication outline by putting a little particle into the coupling site of the DNA/BSA targets particularly in a non-covalent mode. The most suitable binding mode, binding site and possible interactions of the complexes with DNA/BSA could be probed using this study. By using X-ray structural pattern of the human DNA topoisomerase I and BSA

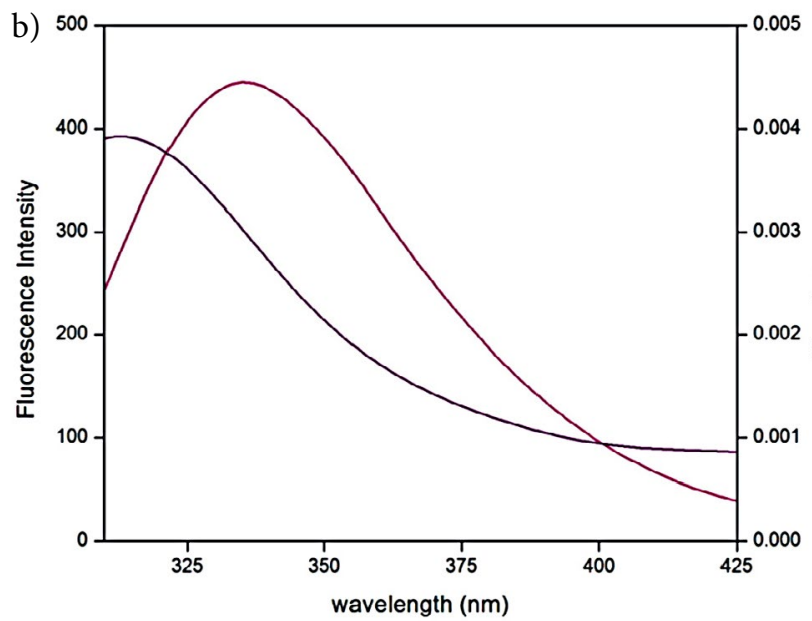

Fig 9: Spectral overlap of UV-Vis absorption spectrum of metal complexes with the fluorescence emission spectrum of BSA. $c($ BSA $)=c($ Metal complex) $=2 \times 10^{-6} \mathrm{~mol} \mathrm{~L}^{-1}, T=298 \mathrm{~K}$ (a) Spectral overlap of MnL (b) Spectral overlap of FeL 
a)

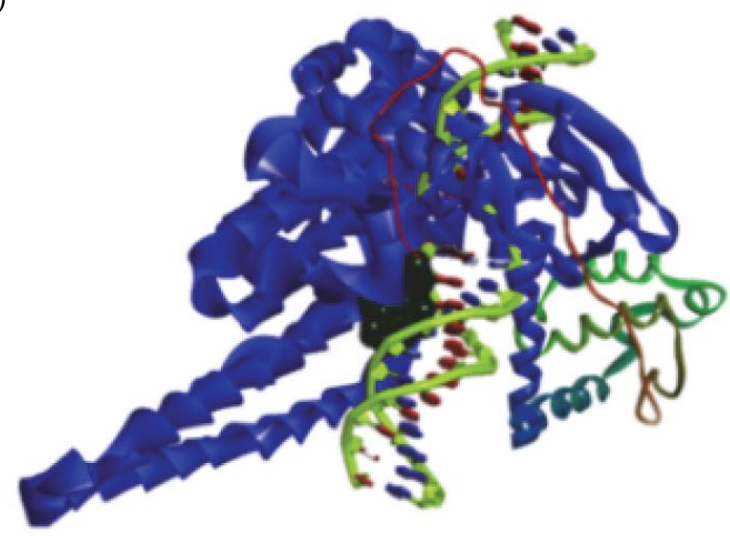

c)

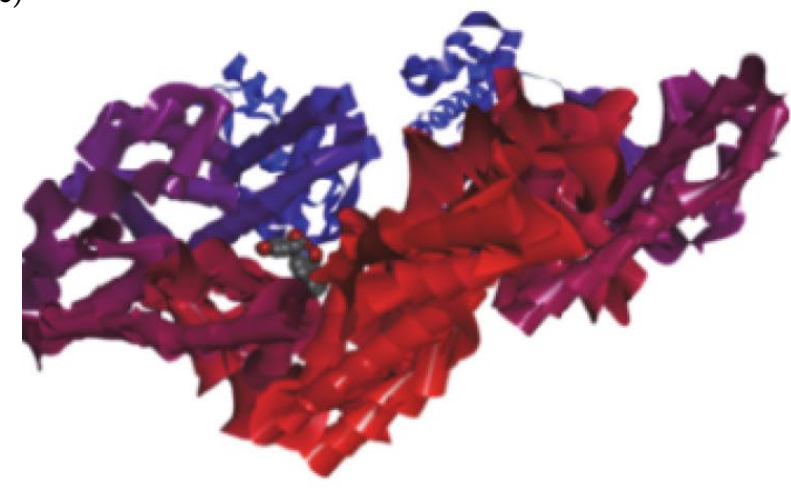

b)

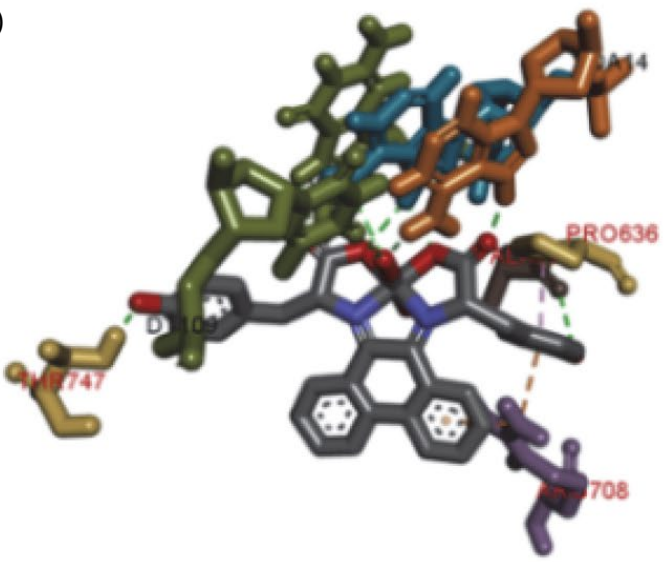

d)

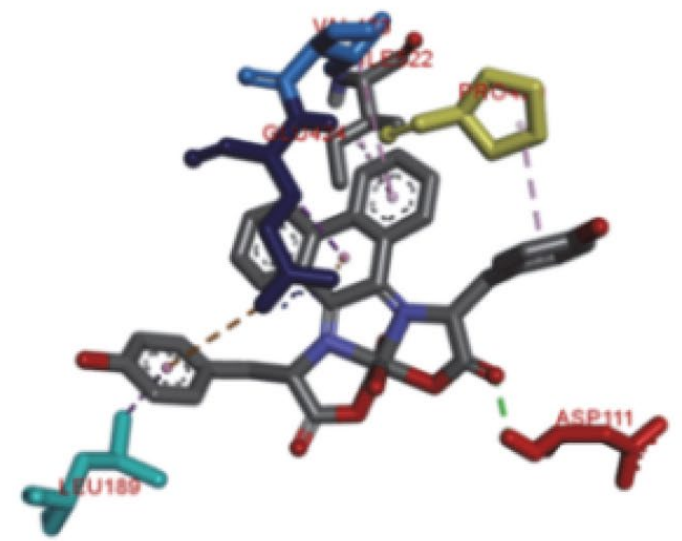

Fig. 10: (a) Molecular docked model of MnL with DNA. (b) specific interaction of MnL with DNA(c) Molecular docked model of MnL with BSA. (d) specific interaction of $\mathrm{MnL}$ with BSA

(downloaded from RCSB PDB) ${ }^{53}$ the molecular docking of the complexes were carried out. Interactions of the complexes with the receptors DNA-topoisomerase I and BSA along with most preferable binding sites are given in Fig. 10 for MnL and Fig. 11 for FeL. The binding energies of the $\mathrm{MnL}$ and FeL complexes with DNA were found to be -11.8 and $-11.7 \mathrm{kcal} \mathrm{mol}^{-1}$, respectively. Also it was observed that the binding energies of the $\mathrm{MnL}$ and FeL complexes with BSA were -10.9 and $-10.8 \mathrm{kcal} \mathrm{mol}^{-1}$, respectively. The possible binding modes, bond distances and binding sites for both the complexes are provided in Tables S1-S4.

\section{Conclusion}

A tetradentate Schiff base ligand involving L-tyrosine and 9,10-phenanthrenequinone along with its $\mathrm{Mn}$ (III)/Fe(III) complexes has been synthesized and characterized using various analytical and spectroscopic tools. The absorption and emission spectra and viscosity measurement provides information on intercalative mode of interaction of the metal complexes with CT-DNA. The interaction of the complexes with BSA was studied at three varying temperatures and observed that the fluorescence quenching process may be accomplished as static quenching. The changes in enthalpy and entropy are ascertained to electrostatic interaction between the $\mathrm{Mn}(\mathrm{III}) / \mathrm{Fe}(\mathrm{III})$ complexes and BSA. The distance between the BSA and $\mathrm{MnL}$ and FeL was found to be 5.91 and 3.20, respectively, which indicates that the energy transfer occurs with high possibility. These results reveal that the synthesised $\mathrm{Mn}$ (III)/Fe(III) complexes could be promising compounds as target-based drugs.

\section{Supporting Information Summary}

The experimental details of DNA/BSA binding and chemical nuclease activity, spectral techniques used such as FTIR, ${ }^{13} \mathrm{C}$ NMR, Mass, absorption and emission titrations and tables for binding energy values of this work can be found in supplementary information.

\section{Acknowledgement}

The authors thank SAIF, Indian Institute of Technology, Madras for providing EI-mass spectra. The authors 
a)

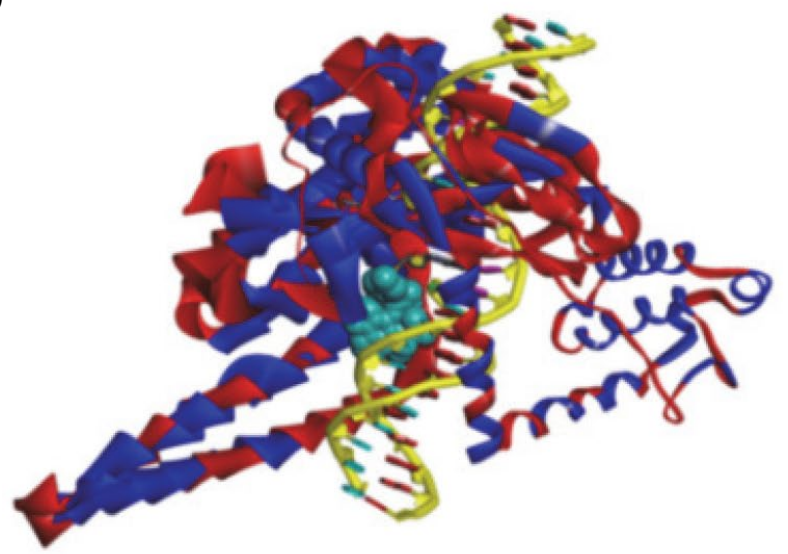

c)

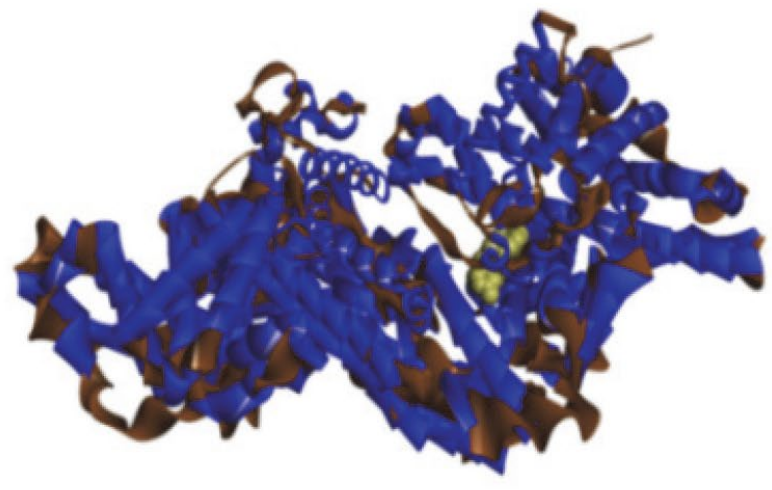

b)

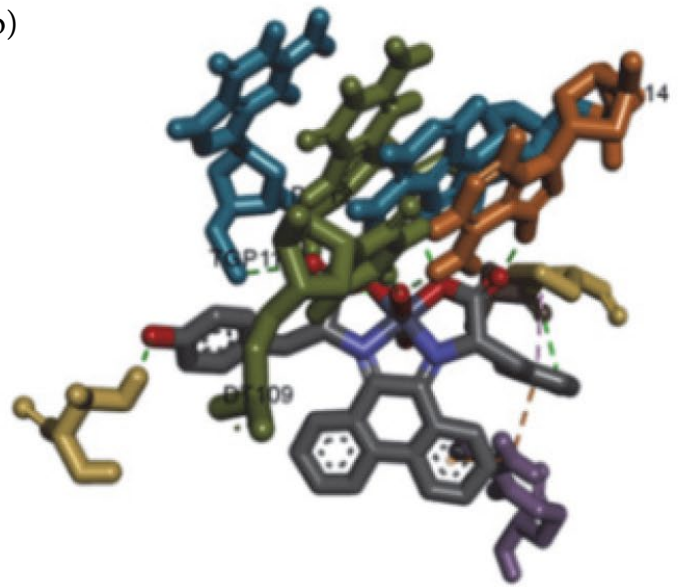

d)

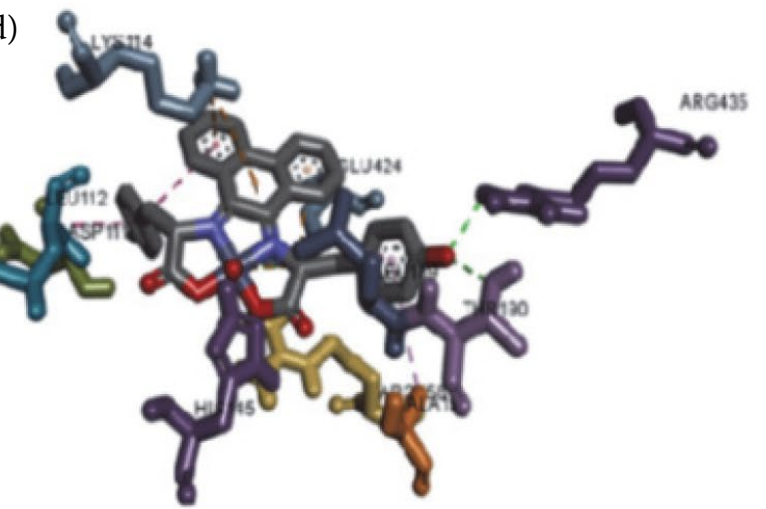

Fig. 11: (a) Molecular docked model of FeL with DNA (b) specific interaction of FeL with DNA(c) Molecular docked model of FeL with BSA (d) specific interaction of FeL with BSA

are thankful to the Vellore Institute of Technology for recording ${ }^{13} \mathrm{C}$ NMR spectra. Also the authors thank BioGenics, Hubli, for the DNA cleavage analysis.

\section{References}

1. S. J. Dixon, B. R. Stockwell, Curr. Opin. Chem. Biol. 2009, 13, 549-555. DOI: 10.1016/j. cbpa.2009.08.003.

2. D. Tietze, M. Tischler, S. Voigt, D. Imhof, O. Ohlenschlager, M. Gorlach, Buntkonwsky, Chem. Eur. J. 2010, 16, 7572-7578. DOI: $10.1002 /$ chem.200903306.

3. S. M. Barnett, K. I. Goldberg, J. M. Mayer, Nat. Chem. 2012, 4, 498-502. DOI: $10.1038 /$ nchem.1350.

4. S. Shaik, Nat Chem. 2010, 2, 347-349.

DOI: $10.1038 /$ nchem.638.

5. L. J. K. Boerner, J. M. Zaleski, Curr. Opin. Chem. Biol. 2005, 9, 135-44. DOI: 10.1016/j.cbpa.2005.02.010.

6. V. C. Silveira, M. P. Abbott, M. Cavicchioli, M. B. Goncalves, H. M. Petrilli, L. De Rezende, A. T. Amaral, D. E. P. Fonseca, G. F. Caramori, A. M. da Costa Ferreira, Dalton Trans. 2013, 42, 6386-6396. DOI: 10.1039/C3DT00108C.

7. A. Patra, T. K. Sen, A. Ghorai, G. T. Musie, S. K. Mandal, U. Ghosh, M. Bera, Inorg. Chem. 2013, 52, 2880-2890.
DOI: $10.1021 /$ ic302099y.

8. X.-W. Li, L. Tao, Y.-T. Li, Z.-Y. Wu, C.-W. Yan, Eur. J. Med. Chem. 2012, 54,697-708.DOI: 10.1016/j.ejmech.2012.06.022.

9. Y. B. Zeng, N. Yang, W. S. Liu, N. Tang, J. Inorg. Biochem. 2003, 97, 258-264. DOI: 10.1016/S0162-0134(03)00313-1.

10. R. Nagane, T. Koshigoe, M. Chikira, J. Inorg. Biochem. 2003, 93, 204-212. DOI: 10.1016/S0162-0134(02)00619-0.

11. A. Silvestri, G. Barone, G. Ruisi, M. Giudice, S. Tumminello, J. Inorg. Biochem. 2004, 98, 589-594.

DOI: 10.1016/j.jinorgbio.2004.01.010.

12. C. Gokce, N. Dilek, R. Gup, Inorg. Chim. Acta 2015, 432, 213 220. DOI: $10.1016 /$ j.ica.2015.03.040.

13. P. Bolel, N. Mahapatra, M. Halder, J. Agric. Food Chem. 2012, 60, 3727-3734. DOI: 10.1021/jf205219w.

14. B. P. Kamat, J. Seetharamappa, J. Pharm. Biomed. Anal. 2004, 35, 655-664. DOI: 10.1016/j.jpba.2004.02.008.

15. B. X. Huang, H. Y. Kim, C. Dass, J. Am. Soc. Mass Spectrom. 2004, 15, 1237-1247. DOI: 10.1016/j.jasms.2004.05.004.

16. S. Ghosh, S. Jana, N. Guchhait, J. Phys. Chem. B 2012, 116, 1155-1163. DOI: 10.1021/jp2094752.

17. D. A. Tinoco, V. E. Eames, D. C. Incarvito, M. A. Valentine, Inorg. Chem. 2008, 47, 8380-8390. DOI: 10.1021/ic800529v.

18. M. Shamsi, S. Yadav, F. Arjmand, J. Photochem. Photobiol. B 2014, 136, 1-11. DOI: 10.1016/j.jphotobiol.2014.04.009. 
19. J. Dong, L. Li, G. Liu, T. Xu, D. Wang, J. Mol. Struct. 2011, 986, 57-63. DOI: 10.1016/j.molstruc.2010.11.036.

20. A. Vogel, Text Book of Quantitative Inorganic Analysis, third ed., ELBS, Longman, London, 1969.

21. L. J. Bellamy, The Infrared Spectra of Complex Molecules, Second ed., Chapman \& Hall, Methuen, London, 1958.

22. S. Cakir, E. Coskun, P. Naumov, E. Bicer, J. Mol. Struct. 2002, 608, 101-107. DOI: 10.1016/S0022-2860(01)00939-5.

23. J. R. Ferraro, Low Frequency Vibrations of Inorganic and Coordination Compounds, Plenum Press, New York, 1971.

24. P. Anitha, R. Manikandan, P. Vijayan, G. Prakash, P. Viswanathamurthi, R. J. Butcher, J. Chem. Sci. 2015, 127, 597-608. DOI: $10.1007 / \mathrm{s} 12039-015-0811-4$

25. A. Gubendran, M. P. Kesavan, S. Ayyanaar, L. Mitu, P. Athappan, J. Rajesh, Spectrochim. Acta A 2017, 181, 39-46.

DOI: $10.1016 /$ j.saa.2017.03.031

26. E. W. Hatfield, E. W. Parker, Inorg. Nucl. Chem. Lett. 1965, 1, 7-9. DOI: 10.1016/S0020-1650(65)80029-0

27. T. Davis, J. Fackler, M. Weeks, Inorg. Chem. 1968, 7, 19942002. DOI: $10.1021 /$ ic50068a007.

28. C. Joel, R. Biju Bennie, S. Daniel Abraham, S. Iyyam Pillai, S. Theodore David, Appl. Organometal. Chem. 2018; e4516. DOI: $10.1002 /$ aoc. 4516.

29. W. J. Geary, Coord. Chem. Rev. 1971, 7, 81-122. DOI: 10.1016/S0010-8545(00)80009-0.

30. N. Raman, A. Selvan, S. Sudharsan, Spectrochim. Acta A, 2011, 79, 873-883. DOI: 10.1016/j.saa.2011.03.017.

31. Y. Li, Z. Y. Yang, Z. Liao, Z. Han, Z. C. Liu, Inorg. Chem. Commun. 2010, 13, 1213-1216.

DOI: $10.1016 /$ j.inoche.2010.07.005.

32. J. K. Barton, A. T. Danishefsky, J. M. Goldberg, J. Am. Chem. Soc. 1984, 106, 2172-2176. DOI: 10.1021/ja00319a043.

33. R. Senthil Kumar, S. Arunachalam, Biophys. Chem. 2008, 136, 136-144. DOI: 10.1016/j.bpc.2008.05.007.

34. L. Jia, P. Jiang, J. Xu, Z. Hao, X. Xu, L. Chen, J. Wu, N. Tang, Q. Wang, J. J. Vittal, Inorg. Chim. Acta 2010, 363, 855-865.

DOI: $10.1016 /$ j.ica.2009.12.047.

35. C. Joel, S. Theodore David, R. Biju Bennie, S. Daniel Abraham, S. Iyyam Pillai, J. Chem. Pharm. Res., 2015, 7, 11591176.
36. P. Anitha, N. Chitrapriya, Y. J. Jang, P. Viswanathamurthi, J. Photochem.Photobiol B: Biol. 2013, 129, 17-26.

DOI: 10.1016/j.jphotobiol.2013.09.005.

37. L. Shi, Y.-Y. Jiang, T. Jiang, W. Yin, J.-P. Yang, M.-L. Cao, Y.-Q. Fang, H.-Y. Liu, Molecules, 2017, 22, 1084, 1-17.

DOI: $10.3390 /$ molecules22071084.

38. S. Bi, Y. Sun, C. Qiao, H. Zhang, C. Liu, J. Lumin. 2009, 129, 541-547. DOI: 10.1016/j.jlumin.2008.12.010.

39. H. X. Zhang, X. Huang, P. Mei, K.H. Li, C. N. Yan, J. Fluoresc. 2006, 16, 287-294. DOI: 10.1007/s10895-006-0087-7.

40. E. L. Gelamo, C. H. T. P. Silva, H. Imasato, M. Tabak, Biochim. Biophys.Acta 2002, 1594, 84-99.

DOI: 10.1016/S0167-4838(01)00287-4.

41. J. R. Lakowicz, G. Weber, Biochemistry, 1973, 12, 4161-4170. DOI: $10.1021 /$ bi00745a020.

42. R. E. Maurice, A. G. Camillo, Anal. Biochem. 1981, 114, 199227. DOI: 10.1016/0003-2697(81)90474-7.

43. Y. J. Hu, Y. Liu, R. M. Zhao, J. X. Dong, S. S. Qu, J. Photochem. Photobiol. A: Chem. 2006, 179, 324-329.

DOI: 10.1016/j.jphotochem.2005.08.037.

44. Y. J. Hu, W. Li, Y. Liu, J. X. Dong, S. S. Qu, J. Pharm. Biomed. Anal. 2005, 39, 740-745. DOI: 10.1016/j.jpba.2005.04.009.

45. M. Gharagozlou, M. D. Boghaei, Spectrochim. Acta A 2008, 71, 1617-1622. DOI: 10.1016/j.saa.2008.06.027.

46. Y. Zhang, B. Zhou, X. Zhang, P. Huang, C. Li, Y. Liu, J. Hazard. Mater. 2009, 163, 1345-1352.

DOI: 10.1016/j.jhazmat.2008.07.132.

47. D. P. Ross, S. Subramanian, Biochemistry 1981, 20, 30963102. DOI: $10.1021 /$ bi00514a017.

48. T. Forster, Modern Quantum Chemistry, Academic Press, New York, 1965, 3, 93-137.

49. W. D. Horrocks, W. E. Collier, J. Am. Chem. Soc. 1981, 103, 2856-2862. DOI: 10.1021/ja00400a061.

50. L. A. Sklar, B. S. Hudson, R. D. Simoni, Biochemistry 1977, 16, 819-828. DOI: 10.1021/bi00624a002.

51. A. Mahammed, H. B. Gray, J. J. Weaver, K. Sorasaenee, Z. Gross, Bioconjugate Chem. 2004, 15, 738-746.

DOI: $10.1021 / \mathrm{bc} 034179$ p.

52. D. J. Li, J. F. Zhu, J. Jin, X. J. Yao, J. Mol. Struct. 2007, 846, 34-41. DOI: 10.1016/j.molstruc.2007.01.020.

53. Protein Data Bank (http://www.rcsb.org/pdb).

\section{Povzetek}

Sintetizirali smo nova Mn(III) in Fe(III) kompleksa z ligandom, ki vsebuje motiv L-tirozina, ter ju okarakterizirali z različnimi analiznimi in spektroskopskimi tehnikami. Kompleksa izkazujeta učinkovite vezne lastnosti z biomolekulami, kot npr. CT-DNA in BSA. Sposobnost kompleksov, da se vežejo na biomolekule, smo raziskovali z absorpcijskimi in emisijskimi metodami in z viskozimetrijo. Na podlagi spektroskopskih tehnik lahko zaključimo, da se kompleksa interkalirata na DNA. Kompleksa lahko cepita pBR322 DNA pri gelski elektroforezi preko oksidativnega mehanizma. BSA je bil kvinčiran s kompleksoma pri približno $340 \mathrm{~nm}$ preko statičnega mehanizma. Določili smo tudi vezne konstante, termodinamske parametre in razdalje donor-akceptor. Nadalje smo z dokingom simulirali nastanek interakcij med kompleksoma in DNA topoizomerazo in BSA proteinom. Simulirane pozicije omogočajo vizualizacijo, ki podpira nastanek interakcij med kompleksoma in DNA/BSA. 